\title{
PERKAWINAN LARI (PAKONDANG) YANG DI LAKUKAN ADAT SUMBA BARAT DI TINJAU UNDANG-UNDANG NO 1 TAHUN 1974 TENTANG PERKAWINAN
}

\author{
Oleh: \\ Marthen Jou Iki* \\ Marthenjouiki@gmail.com \\ Mahasiswa Fakultas Hukum \\ Universitas Gresik \\ Arkisman** \\ Arkismanfhug@gmail.com \\ Dosen Fakultas Hukum \\ Universitas Gresik
}

\begin{abstract}
ABSTRAK
Perkawinan lari (Pakondang) yang terjadi di Sumba Barat Nusa Tenggara Timur merupakan kekaburan norma hukum karena pasangan yang melakukan perkawin lari tidak tidak memberitahukan kepada orang tua tentang keinginan untuk melangsungkan perkawinan, merupakan pasangan yang tidak di restui hubungannya. Rumusan masalah dalam penelitian ini adalah (1) bagaimana proses perkawinan lari yang di lakukan adat Sumba Barat? (2) bagaimana akibat hukum perkawinan lari di Sumba barat berdasarkan Udang-Undang No.1 Tahun 1974?. Penelitian ini adalah penelitan normative dengan data primer yang di kumpulkan dengan metode wawancara sedangkan data sekunder di kaji berdasarkan Undang-Undang. Tenik analisis data yang di gunakan adalah teknik analisis deskriptif. Hasil penelitian di temukan bahwa Undang-Undang Nomor.1 Tahun 1974 tentang perkawinan dapat mencegah terjadinya perkawinan lari (pakondang) di wilayah kabupaten Sumba Barat propinsi Nusa Tenggara Timur dengan melakukan dekontruksi.
\end{abstract}

\section{Kata Kunci :Perkawinan Adat, Pakondang, Undang No 1 Tahun 1974 Tentang} Perkawinan

\section{A.PENDAHULUAN}

Perkawinan adalah suatu perjanjian yang di adakan oleh dua orang antara pria dan wanita yaitu membentuk suatu keluarga atau rumah tangga untuk mempertahankan dan meneruskan kelangsungan hidup dalam masyarakat. Menurut hukum adat suatu ikakatan perkawinan bukan saja berarti bahwa suami dan istri harus saling bantu 
membantu dan melengkapi kehidupan rumah tangganya, tetapi juga berarti ikut sertanya orang tua, keluarga atau kerabat kedua pihak untuk menunjang kebahagiaan dan kekekalan hidup rumah tangga mereka. ${ }^{1}$ Budaya dan aturan perkawinanan suku bangsa di Indonesia sangat beragam, Antara perkawinan dan sifat kekeluargaan terdapat hubungan yang sangat erat. Seperti yang telah di kertahui bahwa Indonesia ini terdapat tiga macam susunan kekeluargaan,yaitu patrilineal, matrilineal, dan parental, yang masing-masing sifat susunan kekeluargaan yang berbeda. ${ }^{2}$ Indonesia yang berlatar belakang Negara kepulauan, terdapat perbedaan budaya, suku, bahasa dan berbagai macam adat istiadat, yang diantaranya masingmasing memiliki tata cara pelaksanaan perkawinan yang antara pulau satu dengan pulau lainnya dan bahkan antara daerah satu dengan daerah lainnya berbeda-beda. Hal ini dapat dilihat cara pelaksanaan perkawinan masyarakat Provinsi Nusa Tenggara Timur pada umumnya dan masyarakat Kabupaten Sumba baratpada khususnya, lebih didasari oleh nilai-nilai yang terkandung dalam ajaran agama kristen, hal ini

\footnotetext{
${ }^{1}$ Hilman Hadikusuma, Hukum Perkawinan Adat, Cet kedua, Alumni, Bandung, 1983, h. 237

${ }^{2}$ Soerojo Wignjodipoero, Pengantar dan Asas- asas Hukum Adat, Cet ketujuh, Cv, Haji Masagung, Jakarta, 1988, h. 12
}

dikarenakan ada hubungan dengan latar belakang masyarakatnya yang mayoritas menganut agama kristen. Masyarakat Kabupaten Sumba Barat di dalam tata cara pelaksanaan perkawinannya, pada dasarnya sama dengan tata cara perkawinan daerah-daerah lain di Indonesia, yaitu yang diawali dengan perkenalan antara muda mudinya yang berlanjut kepada masa penjajakan (pacaran untuk istilah zaman sekarang). Dalam masa penjajakan pasangan muda mudi, masing-masing akan memperkenalkan diri kepada orang tua dan keluarganya. Apabila terjalin kesepahaman, artinya pihak orang tua dan keluarga si wanita menerima kehadiran si laki-laki untuk di jadikan suami bagi anaknya dan begitu pula sebaliknya si laki-laki, maka akan berlanjut ketingkat tata cara pelaksanaan perkawinan dengan diawali oleh acara melamar atau peminangan.Akan tetapi, kalau dalam proses memperkenalkan diri kepada masing-masing orang tua, baik itu dilakukan oleh sipemuda/pemudi sendiri maupun melalui perantaraan orang lain terjadi ketidak cocokan atau tidak direstuinya hubungan di antara mereka, yaitu dengan berbagai macam alasan-alasan dan atau pertimbanganpertimbangan, maka dengan demikian pembicaraan tentang pelaksanaan perkawinan tidak dapat dilanjutkan. Berhubung keinginannya ditolak, maka sipemuda menanggung rasa malu dan merasa tidak ada harga dirinya, sehingga 
karena didasari oleh rasa cinta yang sangat mendalam, maka sipemuda dan pemudi akan mengambil jalan pintas, yaitu dengan jalanpakondang yang artinya lari bersama pemuda dan pemudi atas dasar cinta tanpa sepengetahuan orang tua dan keluarganya. Maka penulis mengajukan judul jurnal ilmiah "PERKAWINAN (PAKONDANG) YANG DI LAKUKAN ADAT SUMBA BARAT DI TINJAU UNDANG-UNDANG NOMOR1 TAHUN 1974 TENTANG PERKAWINAN"

Berdasarkan latar belakang yang telah di sampaikan oleh penulis, maka kiranya berikut:

1.Bagaimana proses perkawinan lari adat Sumba Barat?

2.Bagaimana akibat hukum perkawinan lari di Sumba Barat berdasarkan Undang-Undang Nomor 1 tahun 1974 ?

Berdasarkan pada subyek studi dan jenis masalah yang ada, maka dari tiga jenis grand methode yang telah disebutkan, dalam penelitian ini akan digunakan metode penelitian library research atau penelitian kepustakaan. Mengenai penelitiansemacam ini lazimnya juga disebut "Legal Research" atau "LegalResearch Instruction". 3 Bahan hukum primer

${ }^{3}$ Soerjono Soekanto dan Srimamudji, Penelitian Hukum Normatif, Tinjauan Singkat, Cet ketujuhbelas, Rajawali Pers, Jkarta, 2015, h. 23 yang di kumpulkan penulis adalah peraturan perundang-undangan,catatan resmi atau risalah dalam pembuatan perundang-undangan dan untuk bahan hukum sekundernya penulis mempelajari bahan hukum yang berupa semua publikasi tentang hukum yang meliputi buku-buku teks yang terkait dengan perkawinan lari.

\section{B.PEMBAHASAN}

\section{a. Pengertian Perkawinan Menurut Undang-Undang Nomor 1 Tahun 1974 Tentang Perkawinan}

Perkawinan adalah perilaku mahluk ciptaan Tuhan Yang Maha Esa agarkehidupan didunia dapat berkembang. Perkawinan bukan saja terjadi pada manusia, tetapijuga terjadi pada mahluk lainnya. Oleh karena manusia adalah hewan yang berakal, makaperkawinan merupakan salah satu budaya yang beraturan yang mengikuti perkembangan budaya manusia dalam kehidupan masyarakat.

Dalam Bab I Pasal 1 Undang-Undang Nomor 1 Tahun 1974 tentang Perkawinan, pengertian perkawinan adalah ikatan lahir bathin antara seorang pria dan seorang wanitasebagai suami istri dengan tujuan membentuk keluarga yang bahagia dan kekalberdasarkan Ketuhanan Yang Maha Esa. Dengan "ikatan lahir bathin" dimaksudkanbahwa 
perkawinan itu tidak hanya cukup dengan adanya "ikatan lahir" atau "ikatanbathin" saja, tetapi harus keduaduanya.Bahwa ikatan lahir mengungkapkan adanya suatu hubungan hukum antaraseorang pria dan seorang wanita untuk hidup bersama sebagai suami istri. Ikatan bathinmerupakan hal penting dalam perkawinan ini menunjukan bahwa menurut UndangUndang tujuan adanya perkawinan bukanlah semata-mata memenuhi hawa nafsu. ${ }^{4}$

\section{b. Pengertian perkawinan menurut hukum Adat.}

Pengertian perkawinan menurut hukum Adat adalah urusan kerabat, urusan keluarga, urusan masyarakat, urusan martabat dan urusan pribadi dan begitu pula ia menyangkut urusan keagamaan. ${ }^{5}$ Artinya perkawinan itu bukan saja berarti sebagai perikatan perdata, tetapi juga sekaligus merupakan perikatan kekerabatan dan ketetanggaan. Jadi terjadinya suatu ikatan perkawinan bukan semata-mata membawa akibat terhadap hubungan-hubungan keperdataan, seperti hak dan kewajiban suami-istri, harta bersama, kedudukan anak dan kewajiban orang tua, tetapi

${ }^{4}$ Lili Rasjidi.,Hukum Perkawinan Dan Penceraian di Malaysia dan di Indonesia. Alumni, Bandung, 1982, h.8

${ }^{5}$ Hilman Hadaikusuma., Hukum Perkawinan indonesia, Op. Cit, h.23 juga menyangkut tentang hubunganhubungan adat- istiadat, kewarisan, kekeluargaan, kekerabatan dan ketetanggaan serta menyangkut upacaraupacara adat dan keagamaan. Sejauh mana ikatan perkawinan itu membawa akibat hukum dalam "ikatan adat"seperti tentang kedudukan suami dan kedudukan istri, begitu pula dengan kedudukan anak dan pengangkatan anak, kedudukan anak tertua, anak penerus keturunan, anak adat, anak asuh dan lain-lain, dan harta perkawinan, yaitu harta yang timbul akibat terjadinya perkawinan tergantung pada bentuk dan sistem perkawinan adat tersebut. Bagaimana tata tertib adat yang harus dilakukan oleh mereka yang akan melangsungkan perkawinan menurut bentuk dan sistem perkawinan yang berlaku dalam masyarakat UndangUndang Nomor 1 Tahun 1974 tentang Perkawinan tidak mengaturnya. Hal mana berarti terserah kepada selera dan nilai-nilai budaya dari masyarakat yang bersangkutan, asal saja segala sesuatunya tidak bertentangan dengan kepentingan umum.

\section{c. Tujuan Perkawinan}

Tujuan perkawinan yang bersifat kekerabatan pada hukum adat, adalah mempertahankan dan meneruskan keturunan garis kebapaan atau keibuan atau keibubapaan untuk kebahagiaan rumah tangga, keluarga/kerabat untuk memperoleh nilai-nilai adat, budaya dan kedamaian, dan mempertahankan 
kewarisan. ${ }^{6}$ Menurut $\quad$ Undang-Undang Nomor 1 Tahun 1974 tentang Perkawinan, tujuan perkawinan adalah membentuk keluarga(rumah tangga) yang bahagia dan kekal berdasarkan Ketuhanan Yang Maha Esa.

\section{d. Proses perkawinan Lari Yang Di Lakukan Adat Sumba Barat.}

Pada umumnya yang di maksud dengan perkawinan lari atau melarikan adalah bentuk perkawinan yang tidak di dasarkan persetujuan lamaran orang tua, tetapi berdasarkan kemauan sepihak atau kemauan kedua pihak yang bersangkutan. Bertalian dengan permasalahan kawin lari, bahwa perkawinan ini di lakukan untuk menghindarkan diri dari berbagai keharusan dari akibat perkawinan dengan cara pelamaran atau peminangan,atau juga untuk menghindarkan diri dari pihak orang tua sanak dan saudara yang terutama datagnya dari pihak orang tua perempuan. Perkawinan lari (pakondang)yang terjadi di Sumba Barat merupakan kekaburan norma hukum tindakan perkawinan lari merupakan tindakan yang melanggar hukum perkawinan. Karena kedua belah pihak tidak mendapat restu dari kedua orang tua mereka dan biasanya tidak di restui

${ }^{6}$ Soetojo Prawirohadjojo R, Hukum Orang Dan Keluarga, Op. Cit, h. 23 oleh orang tua dari pihak wanita dikarnakan adanya perbedaan status sosial di antara keduanaya, mereka bersepakat untuk meninggalkan kedua orang tua mereka dan tinggal pada salah satu kerabat mereka (keluarga si pria atau wanita). Pada saat mereka melarikan diri si pria akan meninggalkan barang sebagai petunjuk bahwa mereka telah melarikan diri dalam bentuk satu batang parang dan seekor kuda, tergantung pada kemampuan si pria. Sistem ini mirip dengan yang terjadi di daerah lampung yaitu mereka dengan meninggalkan surat atau suatu barang, kadang-kadang sejumlah uang di rumah si wanita, pelarian ini merupakan awal dari perkawinan mereka. Konsekuensi logis dari bentuk atau cara memperoleh jodoh dengan cara kawin lari (pakondang) di atas adalah pihak keluarga laki-laki harus berani mempertanggung jawabkan perbuatannya yakni dengan di tandai pembayaran sejumlah belis (kerbau, kuda, sapi, kepingan emas atau mamuli) dan lainnya dan pembayarannya di atur berdasarkan tahapan-tahapan tertentu. Menurut kepala desa Taramanu Wanukaka Koki Hida apabila seorang pria yang sudah melakukan kawin lari (pakondang) harus berani utuk mempertanggung jawabkan perbuatannya. Karena pada umumnya perbuatan kawin lari merupakan perbuatan yang melanggar hukum adat, melanggar kekuasaan orang tua dan 
kerabat pihak gadis. ${ }^{7}$ Namun demikian dikarenakan masyarakat adat itu berpegang teguh pada azas kerukunan dan kedamaian, maka perbuatan kawin lari itu dapat di maafkan dengan penyelesaian perundingan kerabat kedua belah pihak. Menurut Tokoh adat Touwa Poga Masalah pertama yang harus dibicarakan sebelum melaksanakan perkawinan adat Sumba Baratadalah masalah belis yang artinya harta yang diperoleh oleh kelurga pihak laki-laki, oleh karena itu dalam masyarakat adat Sumba Barat pihak keluarga si laki-laki harus menyerahkan belis kepada pihak kelurga si wanita. Belis yang di berikan itu biasanaya berupa parang, kerbau, kuda, keping emas (mamuli). Sedangkan jumlahnya selalu merupakan hasil kesepakatan dari kedua belah pihak keluarga si laki-laki dan pihak kelurga si wanita. Dari sini juga terbukti bahwa masalah perkawinan itu dalam masyarakat adat Sumba Barat masalah perkawinan itu bukan hanya pada orang yang mau menikah tetapi melainkan juga merupakan masalah dari keluarga dari masing-masing kedua belah pihak. ${ }^{8}$ Dalam pemikiran umum dalam arti belis yang kita kenal sehari-hari adalah bahwa kata belis selalu di artikan sebagai mahar

\footnotetext{
7 Wawancara dengan Kepala Desa Taramanu Wanukaka, Koki Hida, Tanggal 26 Maret 2019

8 Wawancara dengan Tokoh Adat Touwa Poga Pada tanggal 27 maret 2019
}

atua harga, solah-olah si wanita itu di beli oleh kelurga si laki-laki, maka dengan itu kalau sudah di beli berarti hubungan keluarganya sudah putus, sehingga orang tua si wanita tidak mempunyai hak lagi terhadap anak perempuannya, pengertian yang demikian sebenarnya kurang tepat karena kita melihat struktur derajat, pihak kelurga wanita adalah pihak yang sanagt di hormati oleh keluarga pihak laki-laki dalam masyarakat adat Sumba Barat. Oleh karena itu maka pengertian dari pemberian dari kata belis adalah merupakan penghormatan kepada keluarga pihak perempuan berupa persembahan, agar memberikan anak perempuannya sebagai istri dari anak laki-laki pilihan hati dari anak perempuannya tersebut. Maka dengan di terimanya belis maka anak perempuannya di lepaskan dari golongan sanak marga ayahnya. Istilah ini bukan berarti merupakan putusnya hubungan keluarga dari si wanita tersebut dengan pihak keluarganya, artinya di sini di maksudkan adalah apabila nantinya si wanita tersebut melahirkan seorang anak yang dilahirkan nantinya bukan lagi mengikuti marga daribapak si wanita tersebut, akan tetapi akan mengikuti marga dari suami si wanita tersebut, pemberian belis kepda pihak keluarga wanita juga mengikibatkan adanya pergeseran harta kekayaan dari pihak keluaraga anak laki-laki kepda pihak keluarga perempuan tersebut. 
Kawin lari ( pakondang) dalam adat Sumba Barat sendiri dapat dibedakan menjadi 2 bagian, yaitu: ${ }^{9}$

\section{Kawin lari (pakondang) yang di adati}

Kawin lari (pakondang) yang di adati adalah kawin lari yangterjadi di dalam masyarakat adat Sumba Barat, dimana perkawinan dilaksanakan dengan proses kawin lari namun tetap di lakukan acara adat yang di sebut dengan mangadati, yang di laksanakan di akhir acara perkawinan. Proses kawin lari ini hampir sama dengan proses perkawinan yang idealnya , hanya saja langkah-langkah yang di lakukan lebih sederhana dan si perempuan yang hendak kawin lari tetap harus di bawa ke rumah keluarga si lelaki dan di titipkan di rumah penatua agama sebelum pemberkatan.Kawin lari (pakondang) yang di adati seperti ini biasanya terjadi karena pengaruh ekonomi dimana pihak lelaki tidak dapat memenuhi biaya yang di minta oleh pihak keluarga si perempuan, namun keluarga kedua belah pihak telah setuju dan sepakat untuk melakukan perkawinan pakaondang dan tetap dilaksanakan adat (mangadati), sehingga di kemudian hari tidak perlu lagi dilakukan acara adatnya. kedua belah pihak keluarga mengetahui dan memberi ijin untuk melaksanakan hal tersebut,

\footnotetext{
9 Wawancara dengan Kepala Desa Taramanu Wanukaka pada tanggal 26 Maret 2019
}

karena memang cara itulah yang dianggap tepat pada saat itu agar perkawinan tetap bisa dilaksanakan.

\section{Kawin lari (pakondang) tidak di adati}

Kawin lari (pakondang) tidak di adati adalah kawin lari yangterjadi di dalam masyarakat adat Sumba Barat, dimana perkawinan dilaksanakan dengan proses kawin lari tanpa dilakukan acara adatnya atau tanpa mangadati. Kawin lari (pakondang) seperti ini terjadi karena beberapafaktor seperti faktor ekonomi, tidak mendapat persetujuan, maupun perbedaan agama. Kawin lari (pakondang) tidak di adati ini adalah perkawinan yang dianggap belum sah secara adat sehingga pasangan yang melakukan perkawinan lari ini haruslah memenuhi kewajiban adatnya dengan melakukan acara mangadati nantinya ketika mereka telah siap secara materi yang di dahului dengan pelaksanaan acara adat meminta maaf kepada keluarga si perempuan dengan menyembah karena telah membawa anak perempuannya kawin lari (pakondang). Dalam perkawinan pakondang ini tentu ada cara yang lazim dilakukan oleh pelaku-pelakunya. Yang sering terjadi adalah keluarga si lelaki yang memegang peranan dalam pelaksanaan perkawinan ini karena si lelaki lah yang telah membawasi perempuan untuk melakukan kawin lari (pakondang). Dalam pelaksanaan pakondangini dilakukan dengan cara yaitu : Seperti 
yang telah di bahas di atas bahwa kawin lari (pakondang) tidak diadati adalah kawin lari yang terjadi di dalam masyarakat Sumba Barat,dimana perkawinan dilaksanakan dengan proses pakondangtanpa dilakukan acaraadatnya atau tanpa mangadati, karena berbagai faktor seperti faktor ekonomi, lamaran di tolak dan bahkan beberapa keharusan lainnya yang tidak dapat di penuhi pihak laki-laki. Dimana sebelum si gadis berangkat kawin lari, si gadis meninggalkan informasi kepada orang tuanya. Dahulu cara yang dilakukan ialah meninggalkan parang lelakinya yang diletakkan di bawah tikar. Sebagai langkah pertama, perempuan yang di bawa kawin lari pergi kerumah keluarga pihak lelaki yang terpercaya lalu di antar ke tempat penatua agama dan dirumah tersebut calon pengantin perempuan dititipkan sampai pada tanggal pemberkatan yang di tentukan, hal itu bertujuan untuk dilakukan pendekatan antara ibu penatua gereja (yang bertindak sebagai pihak ketiga)terhadap si gadis yang hendak melaksanakan kawin lari (pakondang) tersebut sehingga di ketahui keadaan sebenarnya apakah si gadis dan si pemuda yang hendak melakukan kawin lari (pakondang) tersebut masih layak menerima pemberkatan di gereja dan demi menjaga kehormatan kedua calon pengantin. Atas kesepakatan orangtua si pemuda dengan pihak pengurus gereja,pasangan yang kawin lari ini di berkati di gereja atau di rumah keluarga si pemuda.Pemberkatan tersebut dilaksanakan sesuai dengan waktu yang telah direncanakan dan di tetapkan antara keluarga si pemuda dengan pihak gereja.Sesuai pemberkatan, diadakanlah acara perjamuan ala kadarnya. Artinya perkawinan itu dilakukan dengan Pendeta.Untuk perjamuan yang dilakukan, tersebut seekor anak babi disembelih dan dimasak secara khas. Undangan yang hadir di acara ini adalah unsur pihak keluarga laki-laki dan kerabat lainnya minimal yang semarga.Dalam pelaksanan pemberkatan dan perjamuan yang ala kadarnya ini pihak keluarga perempuan tidak hadir dan kalaupun hadir biasanya keluarga pihak perempuan hanya mengikuti acara pemberkatan saja namun tidak ikut dalam acara perjamuan yang ala kadarnya tersebut melainkan pulang ke rumahnya, karena pantang baginya untuk memakan makanan di acara tersebut.Setelah selesai makan, seorang laki-laki yang semarga dengan si pemuda di suruh segera mengantar informasi tersebut ke salah satu kerabat dekat dari orangtua si gadis. Penyampaian informasi itu adalah merupakan informasi resmi secara adat kepada orangtua si gadis, bahwa anak gadisnya sudah nikahi (dijadikan istri) oleh pemuda yang mencintainya.Utusan yang mengantar informasi itu, berkata dengan mimik agak takut.informasi ini segera di sampaikan ke orangtua si 
gadis, agar pihak keluarga perempuan tidak meneruskan lagi pencarian atau pelacakannya. Hari berikutnya orangtua si pemuda selalu mencari informasi, sejauh mana kemarahan orangtua si perempuan.Apabila diketahui rasa marah itu sudah redamaka hari untuk pelaksanaan acara adat minta maaf akan di lakukan. Acara ini adalah acara minta maaf kepada orangtua yang anaknya di bawa kawin lari. Pihak keluarga perempuan mengundang semua keluarganya untuk menerima kedatangan keluarga pihak laki-laki yang datang minta maaf. Hal ini bertujuan agarpasangan yang telah melakukan kawin lari (pakondang) itu dapat dengan bebas datang berkunjung ke rumah orangtua si perempuan. Dalam acara minta maaf ini sebelum pihak keluarga laki-laki masuk haruslah menyiapkan satu batang parang dan satu ekor kuda jantan dan nantinya di serahkan kepada pihak keluarga perempuan agar di perbolehkan masuk. Parang dan kuda ini adalah tanda minta maaf pihak laki-laki karena telah melakukan kawin lari. Dan sementara pihak keluarga perempuan menyiapkan dua lembar kain tenun adat Sumba dan satu ekor babi untuk nantinya di serahkan kedua pengantin tersebut. Setelah itu hal pertama yang di lakukan pihak keluarga perempuan adalah bertanya maksud dan tujuan kedatangan pihak keluarga laki-laki, sehingga lebih tegas dan jelas. Ini lah acara sebagai bukti permintaan maaf kedua pengantin dan mengakui kesalahannya kepada orangtua perempuan. Acara minta maaf ini di akhiri dengan penyampaikan nasihat, pengarahan dan pemberian satu lembar kain tenun adat Sumba kepada laki-laki dan satu lembar kepada perempuan (pengantin) dan satu ekor babi oleh orangtua perempuan sebagai tanda mereka telah di terima kembali dalam keluarga itu, serta menyampaikan harapan agar pihak laki-laki segera mengupayakan pesta adat pengukuhan perkawinan tersebut yaitu mengadati, dan di akhiri dengan doa penutup.

Bila sepasang suami istri yang perkawinannya belum dikukuhkan secara adat budaya Sumba, berniat mengadakan pesta adat, langkah pertama yang dilakukan pihak kelurga laki-laki dan pihak kelurga perempuan adalah menghubungi pihak keluarga masingmasing untuk melakukan musyawarah Apabila sudah sama-sama sepakat,maka pihak laki-laki mengirimkan juru bicara (juber) untuk menjajaki hal-halyang menyangkut materi yang akan di siapkan oleh pihak laki-laki yang berupa kerbau, kuda,sapi, parang dan keping emas (mamuli) yang nantinya di berikan ke pihak keluarga perempuan untuk melaksanakan pesta adat tersebut. Adanya suatu perkawinan akan menimbulkan akibat hukum. Secara umum ada 3 (tiga) akibat hukum dari 
perkawinan pakondang, yaitu: ${ }^{10}$ masalah hubungan suami-isteri, masalah hubungan orangtua dengan anak, dan masalah harta benda.

\section{C.PENUTUP}

\section{Kesimpulan}

Dari pembahasan dan analisa yang telah penulis paparkan diatas, maka dapatlah ditarikkesimpulan sebagai berikut :

1. Undang-Undang Nomor 1 Tahun 1974 tentang Perkawinan dapat mencegah terjadinya perkawinan lari (pakondong)di Kabupaten Sumba Barat Propinsi Nusa Tenggara Timur dengan melakukan dekonstruksi perilaku masyarakat yaitu merubah pola pemikiran masyarakat dengan mengadakan sosialisasi UndangUndang Nomor 1 Tahun 1974 Tentang Perkawinan sehingga masyarakat dapat mengetahui dan memahami secara penuh bahwa tindakan kawin lari yang dilakukan pasangan muda-mudi dapat dijerat hukum dan dapat di kenakan sanksi adat.

2. Pihak yang melaksanakan perkawinan lari (pakondong) Kabupaten Sumba Barat Propinsi NTT dapat katakan sahsecara adat dan tradisi yang berlaku pada

\footnotetext{
${ }^{10}$ K.Wantjik Saleh, Hukum Perkawinan Indonesia, Jakarta:Ghalia Indonesia, 1976, h. 33.
}

masyarakat setempat. Proses sahnya perkawinan lari (pakondong) diawali oleh mempelai laki-laki menyampaikan laporan kepada kepala desa bahwa telah membawa lari anak gadis dan tinggal bersamanya, sehingga ditanggapi oleh kepala desa dengan menyampaikan informasi laporan kepada orang tua sang gadis. Tahap selanjutnya pihak orang tua mempelai perempuan dengan berat hati harus mengikuti kondisi yang telah terjadi yaitu dengan membawa kain sebagai lambang bahwa mereka menyetujui hubungan yang telah terjadi (terlanjur). Tahap selanjutnya sebagai tanda hormat dan tanggung jawab kepada orang tua mempelai perempuan, maka pihak keluarga laki-laki akan menyembelih satu ekor babi yang dikonsumsi bersama pada saat acara berlangsung dan menyerahkan satu ekor kuda sebagai lambang permintaan maaf terhadap kekeliruan yang telah dilakukan.

\section{Saran}

Berdasarkan kesimpulan penelitian, maka pada kesempatan ini penulis ingin mengemukakan saran-saran sebagai berikut :

1. Kepada pemerintah pada unit terkecil seperti kepala desa perlunya penyebarluasan atau 


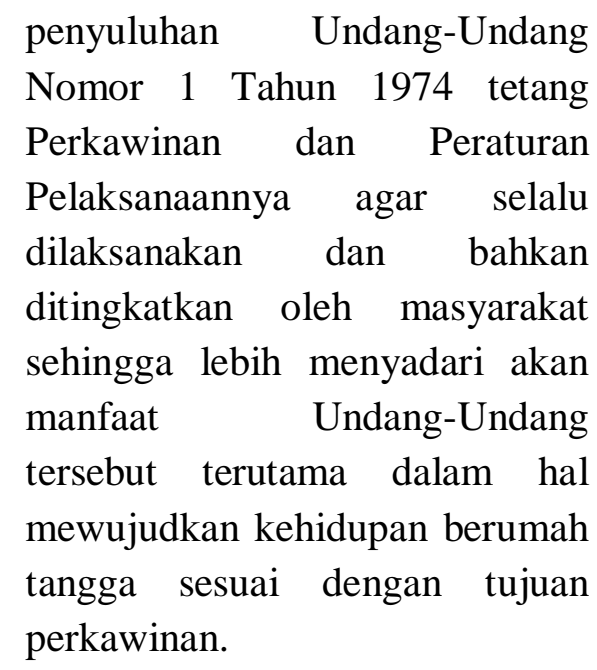

2. Walaupun perkawinan

pakondong merupakan salah satu sistem perkawinan yang dibenarkan dan dapat disahkan kebiasaan masyarakat Sumba Barat tapi sistem perkawinan tersebut belum merupakan sistem perkawinan yang ideal. Dengan berlakunya Undang-Undang Nomor 1 Tahun 1974 tentang Perkawinan hendaknya perkawinan dapat disesuaikan atau menyesuaikan diri terutama dalam menentukan batas umur untuk melangsungkan perkawinan, ijin orang tua dan pencatatan perkawinan.

\section{DAFTAR PUSTAKA}

Hilman Hadikusuma, 1983, Hukum Perkawinan Adat, Cet kedua, Alumni, Bandung

Lili Rasjidi,1982,Hukum

Perkawinan Dan Penceraian di Malaysia dan di Indonesia. Alumni, Bandung
Soerojo Wignjodipoero, 1988, Pengantar dan Asas- asas Hukum Adat, Cet ketujuh, Cv, Haji Masagung, Jakarta Soerjono Soekanto dan Srimamudji, 2015, Penelitian Hukum Normatif, Tinjauan Singkat, Cet ketujuhbelas, Rajawali Pers, Jakarta 